\title{
Measuring Legislative Power: An Expert Reweighting of the Fish-Kroenig Parliamentary Powers Index ${ }^{1}$
}

\author{
Svitlana Chernykh \\ School of Politics and International Relations \\ Australian National University \\ David Doyle \\ Department of Politics and International Relations \\ University of Oxford \\ Timothy J. Power \\ Department of Politics and International Relations \\ University of Oxford
}

\begin{abstract}
The Parliamentary Powers Index (PPI) developed by Fish and Kroenig (2009) is the most important effort to date to measure legislative power in cross-national perspective, but it has been criticized on both theoretical and methodological grounds. We build on the 32-item PPI to develop an alternative indicator of legislative strength that is based on an expert survey of 296 political scientists in 2014. We reweight each of the powers by expert opinion, creating a new Weighted Legislative Powers Score (WLPS) for the 158 national legislatures in the Fish and Kroenig dataset. In addition, the article reports the expert-assigned weight factors for the entire set of 32 powers contained in the original PPI, thus allowing researchers to innovate alternative, disaggregated indicators of legislative power.
\end{abstract}


How should we measure the power of legislative bodies? Surprisingly, only in recent years has this question become central to comparative legislative studies. Beginning in the mid-1990s, there was an explosion in the production of cross-national political variables of all types, including new indicators of presidential power, party system institutionalization, electoral system design, constitutional isomorphism, cabinet stability, judicial independence, and the like. ${ }^{2}$ Surprisingly enough, legislative power was not initially a concern of this measurement revolution. Empirically, the executive-centric nature of numerous Third Wave democracies and the classification of many new legislatures as "reactive" seemed to downgrade their relevance. Theoretically, many studies seemed to assume that the power of the assembly could be inferred from the power of other institutions (for example, as the complement of presidential power in the context of executive-legislative relations) or could be adequately captured by looking to nonlegislative elements of formal institutional design (for example, via assumptions about legislative behavior based on electoral system incentives). Little attention was given to direct measurement of powers specific to elected legislatures.

This scenario changed in 2009 with the publication of Steven Fish and Matthew Kroenig's Handbook of National Legislatures. Relying on a major expert survey using country specialists, Fish and Kroenig were able to generate a measure of legislative power for 158 countries circa 2005. This indicator, known as the Parliamentary Powers Index (PPI), essentially counts the presence or absence, in each country case, of 32 investigator-defined attributes ("powers") of legislative assemblies. Fish and Kroenig's work is by far the most ambitious effort to date to quantify the power of legislative bodies, and is a praiseworthy achievement by any standard. However, some early reviewers of the indicator (e.g. Desposato 2012) have raised serious conceptual and methodological objections to the PPI. Although several of these 
criticisms have been thoughtfully rebutted by the original investigators (Fish and Kroenig 2012), some fundamental issues remain, and these recommend some theoretical and operational adjustments to their original measurement of legislative power.

In this article, we build on Fish and Kroenig's excellent data collection efforts. We report the results of our own expert survey, conducted in 2014, in which political scientists were asked to evaluate the importance of the 32 researcher-defined powers included in the PPI. This allows us to re-weight the component variables in the indicator, generating more nuanced distinctions about what is more or less important with regard to the substantive content of legislative power. With these new weighted measures of legislative power, we can reconstruct the PPI. What our new indicator demonstrates is that while scholars do strongly disagree with Fish and Kroenig's original decision to weight each legislative power equally, this has few practical implications for cross-national measurement of legislative power. Our reweighted index is highly correlated with the original PPI. This is good news for scholars of legislative studies as we demonstrate that a widely adopted index in the sub-discipline can be used robustly in cross-sectional research designs.

The article proceeds as follows. First, we review the main criticisms applied to the PPI and propose some concrete solutions. Second, we describe the methodology used in our own expert survey of 2014, which rewarded us with the input of 296 colleagues. Third, we report our empirical results. We illustrate the expert upweighting or downweighting of the 32 constituent variables posed by Fish and Kroenig. We also discuss the variation in responses, and corresponding measures of uncertainty, across the 32 forms of legislative power, as well as across different types of academic expertise. We finish our empirical section with a brief discussion about the necessity of including all 32 powers in the index, before reflecting on some 
of the immediate limitations of measures of legislative power and outlining an agenda for future research.

\section{Rethinking the PPI}

The starting point for our analysis is the recent scholarly debate over the construction of the Parliamentary Powers Index. ${ }^{3}$ The PPI has begun to be used in a wide variety of crossnational research projects, ${ }^{4}$ but at the same time it has been questioned on both theoretical and empirical grounds. To date, the main conceptual criticism of the indicator has been that it is not theoretically informed and is based on an expansive menu of sometimes unrelated powers, some of which are institutional while others are behavioral. For example, Desposato (2012) questions the indicator's mixing of formal and informal powers. The main methodological objection to the PPI is a familiar one applied to other "checklist" indicators in the literature: as an additive index, the PPI treats each of the 32 legislative powers as equal in the construction of the measure. ${ }^{5}$

In addition to being theoretically thin, there is a problem of practical utility with a checklist approach: checklists may only weakly discriminate among really-existing legislative bodies. Many of the world's parliaments will generate identical counts of powers, giving them the same score on the PPI. Counts can be substantively asymmetrical and yet produce the same results. For example, a legislative body having only powers 1 through 16 would receive a score of 0.50 , and a country having only powers 17 through 32 would have an identical score of 0.50 even though the two parliaments share not a single attribute between them. Researchers looking for a cross-national measure of legislative power will want something more discerning.

How can these problems be rectified? Desposato offers numerous suggestions, two of which - reweighting of the components of the PPI, and reporting of standard errors for new 
indicators - we explicitly follow below. While we understand his criticism of the PPI as an overly expansive "kitchen sink" approach to measuring legislative power (2012: 395), we also sympathize with the sensible response of Fish and Kroenig (2012: 398): it was always better to collect more information rather than less about the world's parliaments. If Fish and Kroenig erred on the side of inclusiveness, we should view this as a strength and not a weakness of their work. The availability of high-quality information about 32 attributes of 158 parliaments affords us ample space to reweight variables and refine measurement of legislative power, which is precisely the strategy advocated by Desposato. We also follow Desposato's suggestions regarding data transparency and replicability, noting that our publication of expert weight factors will allow future researchers to refashion or "customize" new indicators of legislative power.

In the following section, we describe how these objectives were achieved via the generous input of 296 colleagues in political science.

\section{An Expert Survey of Legislative Powers}

Both the Fish and Kroenig 2009 study and the present study are based on expert surveys. Such surveys not only provide an economical way to obtain information, as they can be administered any time and allow consultation with a large number of experts around the world, but in practice they are often the only way to collect information to measure a phenomenon that cannot be observed directly.

As any colleague with an email inbox knows, expert surveys are becoming more and more widely used in political science research. Expert judgments have been used to measure policy positions of presidents and political parties (Wiesehomeier and Benoit 2009; Benoit and Laver 2005, 2006; Huber and Inglehart 1995; Rohrschneider and Whitefield 2012), electoral 
integrity (Martínez i Coma and van Ham 2013), powers of prime ministers (O’Malley 2007), democracy (Coppedge, Gerring, and Lindberg 2012, Freedom House), and quality of government (Teorell, Dahlströ and Dahlberg 2011), among many other variables.

The Fish and Kroenig PPI was also generated by using expert judgments about the presence or absence of 32 legislative powers in 158 countries (Fish and Kroenig 2009). Building on this effort, we designed a follow-up survey aimed to ascribe weights to each of the attributes of parliaments used to construct the original index. The survey was designed using LimeService, an online survey service-platform that enables implementation of surveys via email. Our questionnaire included a total of 35 response items and took on average 20 minutes to complete.

First, our respondents were asked to rate the importance of 32 legislative powers (the same 32 selected by Fish and Kroenig) on a scale from 1 to 10 . A low score indicated that the respondent believed that the power in question was not very important to the overall strength of a legislature, whereas a higher score indicated his/her belief that the power was very important. Prior to the beginning of the survey, we provided the respondents with a list of the 32 powers that they were asked to inspect. We retained the exact wording of the items used in The Handbook of National Legislatures but presented the powers in a random order (please see Appendix A for the exact wording of each power). ${ }^{6}$ In the invitation email as well as in the introduction to the survey, the respondents were reminded that the survey items did not pertain to any particular political system or region, nor were they being approached as "country specialists" (as was the case with the experts recruited by Fish and Kroenig). Instead, we simply asked our respondents to think with us about the concept of legislative strength in comparative perspective.

Following the rating of each power, we also asked the respondents to indicate how confident they were about each of their answers, using a scale from $10 \%$ to $100 \%$. Lastly, we 
also asked our experts to rate their professional knowledge of nine regions of the world on a scale from 1 to 5 , as well as to indicate their area of specialization and to specify the country focus (if any) of their research. The survey was launched on July 4, 2014. ${ }^{7}$ Each respondent received an invitation email with a link to the survey. The initial invitation email was followed by two reminder emails, each sent within three to four weeks.

The Experts. To identify potential experts, we consulted membership rosters of numerous professional organizations and their respective specialist subgroups. These included the Legislative Studies Section (LSS) of the American Political Science Association (APSA), the Standing Group on Parliaments of the European Consortium for Political Research (ECPR), the Research Committee of Legislative Specialists (RCLS) of the International Political Science Association (IPSA), and the Legislative Studies Group (GEL) of the Latin American Political Science Association (ALACIP). In addition, we also contacted a number of colleagues who participated in the original survey by Fish and Kroenig. However, we limited our contact list to scholars of legislative studies, political institutions, or comparative politics. We excluded political scientists from other subfields, country specialists from other disciplines, and nonacademic professionals. Our inventory yielded a sample of 1030 political scientists whose email addresses we were able to locate. In the end, we recorded 296 completed questionnaires, for a response rate of $28.7 \%$.

\section{[FIGURE 1 HERE]}

Descriptive statistics suggest that we were successful in reaching out to our targeted population. Some $50 \%$ of the respondents identified themselves as specialists in legislative studies, $32 \%$ as experts in comparative political institutions and $12 \%$ as scholars of comparative politics more generally (see Figure 1$)$. The "other" category was selected by only $6 \%(\mathrm{~N}=17) .^{8}$ 
This group consisted mostly of respondents who did not place themselves in any of the broader categories provided in the survey but instead defined their specializations in more narrow terms such as US politics and institutions, parliamentary theory, or post-communist politics.

\section{[FIGURE 2 HERE]}

We contacted experts in all regions of the world, and our final sample is inclusive. As Figure 2 shows, specialists in North America, Latin America, and Western Europe are almost equally represented in our dataset of 296 completed questionnaires, with $31 \%, 24 \%$ and $21 \%$ respectively. ${ }^{9}$ The survey asked about expertise in each region separately, thus potentially allowing respondents to indicate the same level of specialized knowledge in two or more different regions. Figure 2 presents a description of how many colleagues rated their expertise in each of the regions as 5 , the maximum score.

\section{Survey Results}

With the responses from our survey, we can now explore how our experts perceive the relative importance of each of the 32 legislative powers highlighted by Fish and Kroenig (2009). We use the 1-10 rating of importance, assigned by each expert to each power, in order to reweight these legislative powers and construct a new index — based on the original PPI — that we call the Weighted Legislative Powers Score (WLPS). In addition, given that we asked the respondents to rate the level of confidence they had in each weighting they assigned, we can also assess how this self-reported confidence relates to the actual variation in responses we observe.

We begin with the re-weighting of each legislative power. In Figure 3, the left-hand pane graphs the mean importance, on the 1-10 scale, assigned by our expert respondents to each one of the thirty-two legislative powers of the PPI, together with 95 percent confidence intervals. 
These confidence intervals were calculated on the basis of the extent of the divergence among the answers we received. The results are stark. Rather than assuming that all legislative powers are equal as the PPI does, our experts clearly believe that some powers matter more than others. What is more, the difference in the relative importance of the powers is also statistically significant. For our experts, the most important elements of legislative powers include the ability of the legislature to conduct independent investigations of the executive, whether legislators are elected (as opposed to appointed), whether their initiatives can be vetoed by the executive, whether the executive can dissolve the house, the degree to which the legislature controls the financial resources necessary for its own operation, and the power to replace the executive. There is also general agreement among the respondents about the importance of these powers, given the relatively narrow confidence intervals. Similarly, there is also clear agreement among our experts as to what are the least important powers. These include the power of legislatures to grant amnesty, the ability of ministers to serve simultaneously as members of the legislature and the power of pardon. These are ranked even lower than the right of each member of parliament to have a personal secretary, a power singled out by Desposato (2012: 394) as especially unconvincing.

\section{[FIGURE 3 HERE]}

The right-hand pane of Figure 3 explicitly depicts the difference between our reweighted measures and the approach adopted by the PPI. In the construction of the PPI, an additive index, each of the thirty-two powers is considered to contribute equally to the overall power of the assembly. That is, each power accounts for exactly 3.125 per cent of the PPI. Our experts strongly disagree with this assumption. The lines in Figure 3 extend both to the right of 3.125 
(upweighting of a power relative to its contribution to the PPI) and also to the left (representing a downgrading of the power's perceived importance).

This figure lends credence to the overarching exercise: as Desposato (2012) suggested in his critique of the PPI, the constitutive legislative powers should clearly be weighted. ${ }^{10}$ To this end, we included a second question that gives us significant analytical leverage over the data. Following the rating of each power, the experts were asked to indicate how confident they were about each of their answers, using a scale from $10 \%$ to $100 \%$. This approach allows us to get a sense not only of the variation in the concordance among responses, but also of any latent patterns in the distribution of uncertainty among experts.

\section{[FIGURE 4 HERE]}

The left-hand pane of Figure 4 depicts the variation in disagreement among our respondents. Each bar chart represents the standard error of the responses for each particular power. The right-hand pane of Figure 4 captures variation in uncertainty among the experts. It depicts the mean level, and range at the 95 percent level, of self-reported confidence of respondents in their rating of each power. There is a discernible pattern here. Disagreement among respondents is correlated with self-reported uncertainty $(r=-0.246)$. For some powers, such as the power to investigate and veto power, experts are reasonably unanimous in their scoring of these powers, and they are also highly confident in their own ratings. In contrast, for powers such as parliamentary immunity, appointment of the Central Bank governor, and the ability of MPs to serve simultaneously as ministers, there is significant disagreement among our experts, as indicated by the large standard errors. Additionally, our experts also have relatively low levels of confidence in their weighting of these powers.

[FIGURE 5 HERE] 
What is more, there is an even stronger correlation between the importance of these powers, as ranked by our experts, and their own level of subjective self-confidence in these rankings. Figure 5 graphs this relationship between the mean weighting of each power (with 95 percent CIs) and the mean self-reported confidence of our experts in their assessment of these powers. The trend is stark. For the most important legislative powers, the respondents are very confident in their assessments that these powers matter. For the least important powers, the opposite relationship obtains (the correlation coefficient is .80).

Figure 6 highlights further disagreement and uncertainty among our experts according to their area of academic specialization and to the regime type they most frequently study. In the left-hand pane of Figure 6, each bar simply represents the mean standard error in the responses of experts by particular field of expertise - that is, legislative studies, comparative institutions, or comparative politics more generally. The point estimate is the mean level of subjective selfconfidence each group reported in their responses, while the vertical lines centered on each bar show the 95 percent confidence intervals around this mean estimate. We can immediately identify clear idiosyncrasies. The lowest mean standard error (i.e. the least disagreement in ratings), can be found among those who specialize in legislative studies, followed closely by comparativists with a focus on political institutions. In contrast, we can find noticeably more variation among the responses of the general comparativists, and significant variation in the responses from the residual (“other") category $(N=17)$. Not surprisingly, inter-respondent agreement varies positively with proximity to legislative studies.

What is more, subjective self-confidence also varies by area of expertise. Those respondents who primarily study legislatures have the highest mean level of confidence in their responses, and there is general agreement around this level of certainty, as indicated by the 
comparably small CIs. Again, comparativists with a focus on political institutions follow closely behind. While the "other" category reports a high average level of self-confidence in their responses, the size of the confidence intervals suggest that there was significant intra-group variation with regard to certitude. A similar pattern can be observed for generalists in comparative politics. Again and not surprisingly, the subjective competence of our respondents rises in direct proportion to their investment in specialized legislative studies.

\section{[FIGURE 6 HERE]}

We also asked our experts to identify the political systems that they most frequently studied ("Do you specialize in the politics of a specific country or countries?"). On the basis of these responses, we then coded each expert according to the regime type that they most frequently analyzed: parliamentary, presidential, a mixture of both, or none (meaning that the respondents did not consider themselves to be country specialists). The right-hand pane of Figure 6 depicts the disagreement and uncertainty among our experts according to these categories. We can see that the regime types to which our experts are most frequently exposed also drive some idiosyncrasies in their responses. Scholars who focus on pure presidential regimes have the lowest level of disagreement among their responses, as indicted by the low standard error. This group also has a high mean level of self-confidence in their responses, and there is general agreement among experts about this level of confidence. The second lowest level of discordance can be found among scholars of parliamentary regimes, although they exhibit slightly higher levels of uncertainty about their responses. These patterns may be driven by professional and regional effects, i.e., the greater concentration of presidentialism in a single world region (Latin America) and the large and integrated scholarly literature that takes advantage of this geographic association. Although there is the highest degree of disagreement among our experts who 
straddle both regime types, they also have the highest level of certainty about their responses (albeit with some variation here). Those respondents who did not report any country expertiseand whom we could not link to a familiar constitutional format_-are least certain about the validity of their responses and also exhibit significant disagreement in their ratings.

\section{The Weighted Legislative Power Score (WLPS)}

In a final step, we report the final WLPS value for each country originally included in the PPI. ${ }^{11}$ At the cross-national level $(N=158)$, the overall correlation between the PPI and WLPS is very high $(r=0.997)$. This is to be expected given that we have applied a reweighting strategy to an indicator (PPI) that was originally constructed from a count of binary variables. Crosssectional variation in the PPI is determined entirely by absence (0) or presence (1) of powers. When we apply our expert-determined weights to the 32 powers in question, we are reweighting the powers scored as 1 but not the powers scored as 0 , leaving more than half of the original observations unchanged. ${ }^{12}$ Therefore any reweighted indicator will naturally bear a strong resemblance to the original PPI at the global level, as Figure 7 demonstrates. ${ }^{13}$

\section{[FIGURE 7 HERE]}

Yet the high correlation of WLPS with PPI masks two important advantages of the former. First, WLPS generates a significant reordering of countries in terms of legislative strength. Second, WLPS is much more discriminating than PPI in a global "league table" of legislative strength. If we rank our 158 countries from highest to lowest in terms of their legislative power circa 2005, PPI generates only 27 discriminating ranks, with a very high number of "ties." For example, a PPI score of 0.44 , roughly in the middle of the index (just below the mean), is shared by 16 different countries, making it difficult to distinguish among cases in comparative perspective. This is to be expected of an index that is comprised of 32 
unweighted powers, on which many countries share the same count of powers. On the PPI, Germany, Italy, and Mongolia all have identical scores and are tied for first in the global rankings of legislative power (see Appendix B for country data).

Yet WLPS, which assigns expert-generated weight factors to each of the 32 legislative powers selected by Fish and Kroenig, is highly sensitive to the varying combinations of powers that appear around the world. Thus, it is encouraging that a rank-ordering of 158 countries produces 155 discriminating ranks. There are only three "ties." The most notable of these is the tie for last place between Myanmar and Somalia, whose parliaments lack all of the 32 powers identified by Fish and Kroenig.

All in all, the global "league table" of legislative power circa 2005 looks quite different when political scientists are allowed to reweight the 32 powers posed as equal by Fish and Kroenig. We can observe this examining both global patterns associated with regime types (presidential, semipresidential, and parliamentary) as well as specific configurations of powers that change our interpretations of individual legislative bodies. As mentioned earlier, unweighted counts of legislative powers might lead us to believe that two parliaments are similar when they are in fact substantively very different.

At the global level, inspection of the data strongly suggests that PPI incorporates something of a bias against pure presidential regimes. This is likely due to the inclusion of powers such as Lacks Presidency, Appoint PM, and Confidence Vote (see Appendix A). If we compare relative changes in perceived power between PPI and WLPS, we can see that assemblies in presidential systems improve their relative positions when experts are allowed to reweight the importance of legislative attributes. For example, the legislative bodies of the United States, Brazil, and the Philippines all appear more potent under WLPS. In contrast, 
legislatures in parliamentary and especially in semi-presidential systems are downgraded by expert reweighting of powers.

The reweighting exercise also encourages a rethinking of some individual parliaments. Like the United States and Brazil, Norway also does much better under WLPS, even though it is a pure parliamentary system. This is an artifact of the specific arsenal of powers that the Norwegian Storting possesses. Under the PPI scoring, Norway was disadvantaged because it lacked a large number of powers (Appoint Judges, Central Bank, Grant Amnesty, Grant Pardon, Immunity) that were later judged to be less important by our experts and hence are downgraded in WLPS. Yet of the 15 legislative powers most upweighted by our experts relative to PPI (Figure 3, right pane), Norway boasts each and every one of them.

Similar configurational effects are visible in a semi-presidential country with a weaker democratic tradition, Ukraine. Its legislature, the Verkhovna Rada, possesses a large number of powers that are deemed less essential by expert opinion (Appoint Judges, Central Bank, Grant Amnesty, Immunity, Personal Secretary, State Media) and are downgraded in WLPS; but more importantly from a substantive point of view, the Ukrainian parliament lacks most of the main legislative powers that are highly valued by political scientists (No Veto, Replace Executive, No Dissolution, Amend Const, and Investigation). We contend that the power of the Ukrainian assembly is greatly overestimated by the PPI. ${ }^{14}$

As the Norwegian and Ukrainian examples show, the devil is the details: we need to look inside aggregate measures of legislative power in order to see what is driving the results. Yet the Fish and Kroenig method of measurement obviates this sort of inspection, because each of the 32 powers contributes exactly the same amount (3.125\%) to the final indicator. Our Weighted Legislative Powers Score preserves these 32 powers but reweights them according to expert 
opinion, and this simple operation generates some significant changes in how we assess not only constitutional formats but also specific country cases. In our view, the enhanced contextual sensitivity of WLPS makes it an attractive option for use in cross-national quantitative research. ${ }^{15}$

\section{Conclusions}

This article has advanced a new cross-national measure of legislative power based on information originally assembled by Fish and Kroenig (2009) for the construction of their Parliamentary Powers Index. In doing so, it addresses some of the early criticism that the PPI has received. Despite our endorsement of some of these criticisms, we recognise that none of the data analyses in this article would have been possible without the heroic original data collection efforts by Fish and Kroenig. The subfield of legislative studies owes them a debt of gratitude, especially due to their broad approach to the consideration of what constitutes parliamentary power. Their inclusionary method allowed us to submit a large number of powers to the consideration of experts, who then went on to upgrade and downgrade these same powers.

Our research has assigned specific weights to the 32 legislative powers identified by Fish and Kroenig. We report the expert ratings of powers in Appendix E of this article and make them publicly available for the first time. These expert reweightings can now be applied across time in further iterations of surveys based on the PPI or a consequence of de jure constitutional changes. Should they wish, colleagues can now mix and match the specific legislative powers that they wish to investigate, and they can create customized indicators of cross-national legislative power. We expect that in their efforts to generate parsimonious yet discriminating indicators of 
legislative influence, colleagues may now choose to disregard certain powers and to focus on smaller subsets of parliamentary attributes in the future.

In conclusion, we note that both PPI and WLPS remain cross-national snapshots of legislative power at one point in time, built on the original Fish and Kroenig survey of the mid2000s. What we have done in this paper is largely to "retouch" these snapshots by recruiting political scientists to improve the clarity of image. We are not yet in a position to annualize the WLPS observations and render them suitable for research across time as well as across space. However, such a goal is feasible if we take the expert weightings generated by our expert survey and then apply them, wherever possible, to cognate legislative variables that appear in longitudinal databases of comparative political institutions. ${ }^{16}$ This approach may allow us to innovate new time-series data on the power of legislative bodies, allowing us to investigate the causes and consequences of changes in legislative power across time. 
Svitlana Chernykh is a Lecturer in the School of Politics and International Relations at the Australian National University, Acton ACT 2601, Australia (svitlana.chernykh@anu.edu.au). David Doyle is Associate Professor in Latin American Politics and a fellow of St Hugh's College, University of Oxford, Oxford OX2 6LE, United Kingdom (david.doyle@politics.ox.ac.uk). Timothy J. Power is University Lecturer in Brazilian Studies and a fellow of St Antony's College, University of Oxford, OX2 6JF, United Kingdom (timothy.power@lac.ox.ac.uk). 


\section{References}

Aldrich, John H and Richard D. McKelvey. 1977. "A Method of Scaling with Applications to the 1968 and 1972 Presidential Elections." American Political Science Review 71(1): 111-130.

Benoit, Kenneth and Michael Laver. 2005. "Mapping the Irish Policy Space: Voter and Party Spaces in Preferential Elections." Economic and Social Review 32 (2): 83-108.

Benoit, Kenneth and Michael Laver. 2006. Party Policy in Modern Democracies. London: Routledge.

Brady, Henry E. 1985. “The Perils of Survey Research: Inter-Personally Incomparable Responses.” Political Methodology 11 (3-4): 269-291.

Cheibub, José Antonio, Zachary Elkins, and Tom Ginsburg. 2014. "Beyond Presidentialism and Parliamentarism.” British Journal of Political Science 44 (3): 515-544.

Clark, Nicholas. 2014. "Explaining Low Turnout in European Elections: The Role of Issue Salience and Institutional Perceptions in Elections to the European Parliament." Journal of European Integration 36 (4): 339-356.

Coppedge, Michael, John Gerring and Staffan Lindberg. 2012. "Varieties of Democracy Project Description.” Paper presented at the 2012 American Political Science Meeting.

Desposato, Scott. 2012. "Book review of The Handbook of National Legislatures by M. Steven Fish and Matthew Kroenig." Legislative Studies Quarterly 37, no. 3 (August): 389-396.

Doyle, David and Robert Elgie. 2015. "Maximizing the Reliability of Cross-national Measures of Presidential Power." British Journal of Political Science. Online first. DOI: $10.1017 / \mathrm{S} 0007123414000465$. 
Ecevit, Yüksel Alper, and Ekrem Karkoç. 2015. "The Perils of Semi-Presidentialism: Confidence in Political Institutions in Contemporary Democracies." International Political Science Review. Online first: DOI 10.1177/0192512115599243.

Fish, Steven M. and Matthew Kroenig. 2009. The Handbook of National Legislatures: A Global Survey. New York: Cambridge University Press.

Fish, M. Steven and Matthew Kroenig. 2012. “A Response to Desposato.” Legislative Studies Quarterly 37, no. 3 (August): 397-401.

Gerring, John, Philip Bond, William T. Barndt, and Carola Moreno. 2005. "Democracy and Economic Growth: A Historical Perspective.” World Politics 57: 323-364.

Fortin, Jessica. 2013. "Measuring Presidential Powers: Some Pitfalls of Aggregate Measurement." International Political Science Review 34 (1): 91-112.

Hare, Christopher, David Armstrong, Ryan Bakker, Royce Carroll, and Keith Poole. 2014. “Using Bayesian Aldrich-McKelvey Scaling to Study Citizens' Ideological Preferences and Perceptions." American Journal of Political Science 59 (3): 759-774.

Huber, John and Inglehart, Ronald. 1995. "Expert Interpretations of Party Space and Party Locations in 42 Societies," Party Politics 1:73-111.

Jones, Mark. 2010. "Political Parties and Party Systems in Latin America.” In C. Scartascini, E. Stein and M. Tomassi, eds., How Democracy Works: Political Institutions, Actors, and Arenas in Latin American Policymaking, pp. 19-46. Harvard University Press.

King, Gary, Christopher J.L. Murray, Joshua. A. Salomon, Ajay Tandon. 2004. "Enhancing the Validity and Cross-Cultural Comparability of Measurement in Survey Research." American Political Science Review 98 (1): 191-207. 
Mainwaring, Scott and Timothy R. Scully. 1995. Building Democratic Institutions: Party Systems in Latin America. Stanford: Stanford University Press.

Martin, Lanny and Georg Vanberg. 2011. Parliaments and Coalitions: The Role of Legislative Institutions in Multiparty Governance. Oxford: Oxford University Press.

Martínez i Coma, Ferran, and Carolien van Ham. 2013. "Can Expert Judge Elections? Testing the Validity of Expert Judgments for Measuring Election Integrity." Paper presented at the preAPSA Workshop on Electoral Integrity, Chicago, IL.

Martinez-Gallardo, Cecilia and Petra Schleiter. 2014. "Choosing Whom to Trust: Agency Risks and Cabinet Partisanship in Presidential Democracies." Comparative Political Studies. Online First.

Metcalf, Lee Kendall. 2000. "Measuring Presidential Power.” Comparative Politics Studies 33 (5): 660-685.

O'Dwyer, Conor. 2014. "What Accounts for Party System Stability? Comparing the Dimensions of Party Competition in Postcommunist Europe." Europe-Asia Studies 66, no. 4. Online first: DOI 10.1080/09668136.2014.897430.

O’Malley, Eoin. 2007. "The Power of Prime Ministers: Results of an Expert Survey." International Political Science Review 28 (1): 7-27.

Ríos-Figueroa, Julio and Jeffrey Staton. 2012. "An Evaluation of Cross-National measures of Judicial Independence.” The Journal of Law, Economics, and Organization 30 (1): 104-137.

Rohrschneider, Robert and Stephen Whitefield. 2012. The Strain of Representation: How Parties Represent Diverse Voters in Western and Eastern Europe. Oxford: Oxford University Press.

Schwindt-Bayer, Leslie and Peverill Squire. 2014. "Legislative Power and Women's 
Representation." Politics and Gender 10, no. 4 (December): 622-658.

Shugart, Matthew S. and John M. Carey. 1992. Presidents and Assemblies: Constitutional Design and Electoral Dynamics. Cambridge: Cambridge University Press.

Teorell, Jan, Carl Dahlström and Stefan Dahlberg. 2011. The QoG Expert Survey Dataset. University of Gothenburg: The Quality of Government Institute. Available at http://www.qog.pol.gu.se.

Teorell, Jan and Catharina Lindstedt. 2010. "Measuring Electoral Systems." Political Research Quarterly 63, no. 2 (June): 434-448.

Wiesehomeier, Nina and Kenneth Benoit 2009. "Presidents, Parties and Policy Competition." Journal of Politics 71 (4): 1435-1447. 
Figure 1

Self-Reported Thematic Expertise of the 296 Survey Respondents

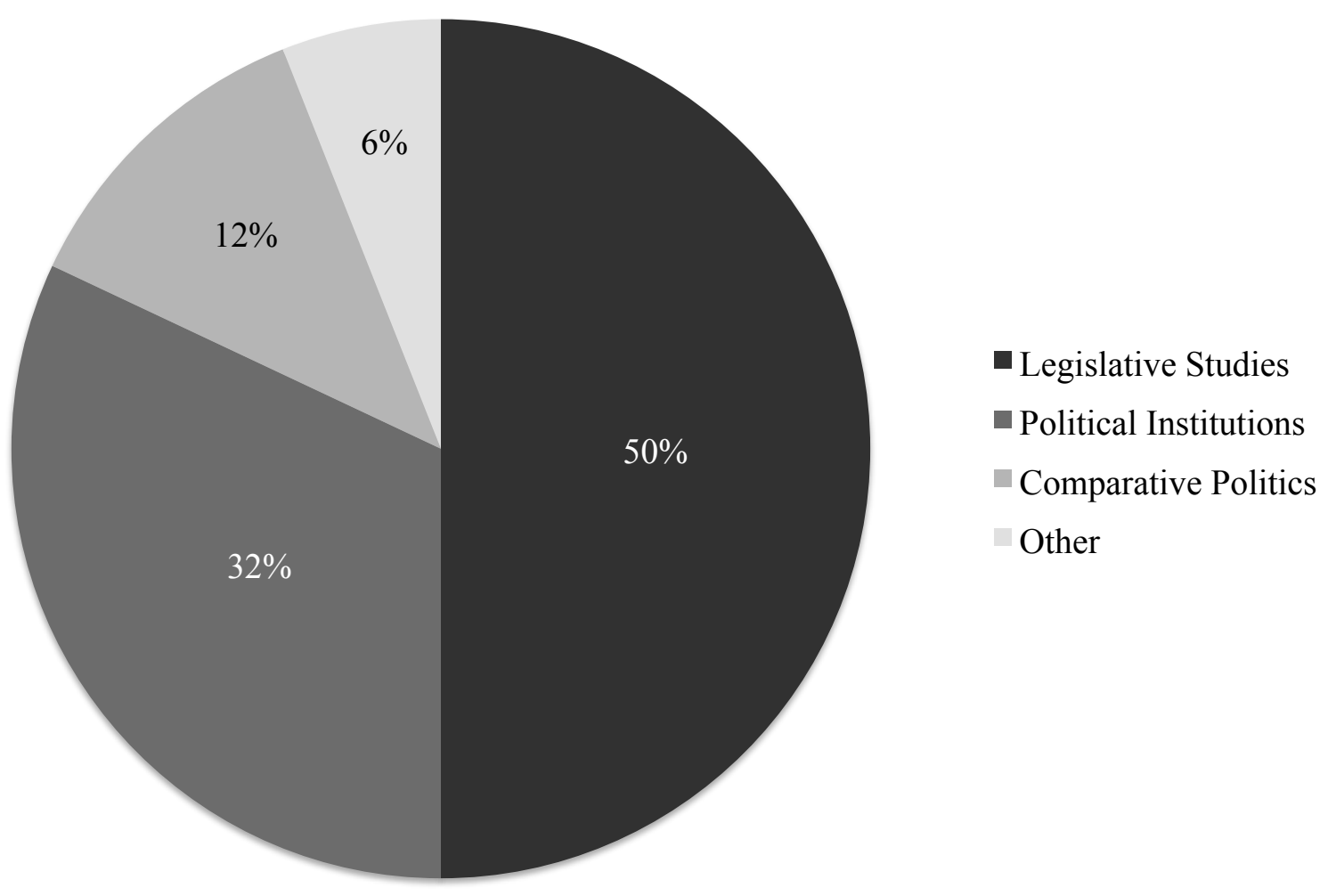


Figure 2

Self-Reported Regional Expertise of the 296 Survey Respondents

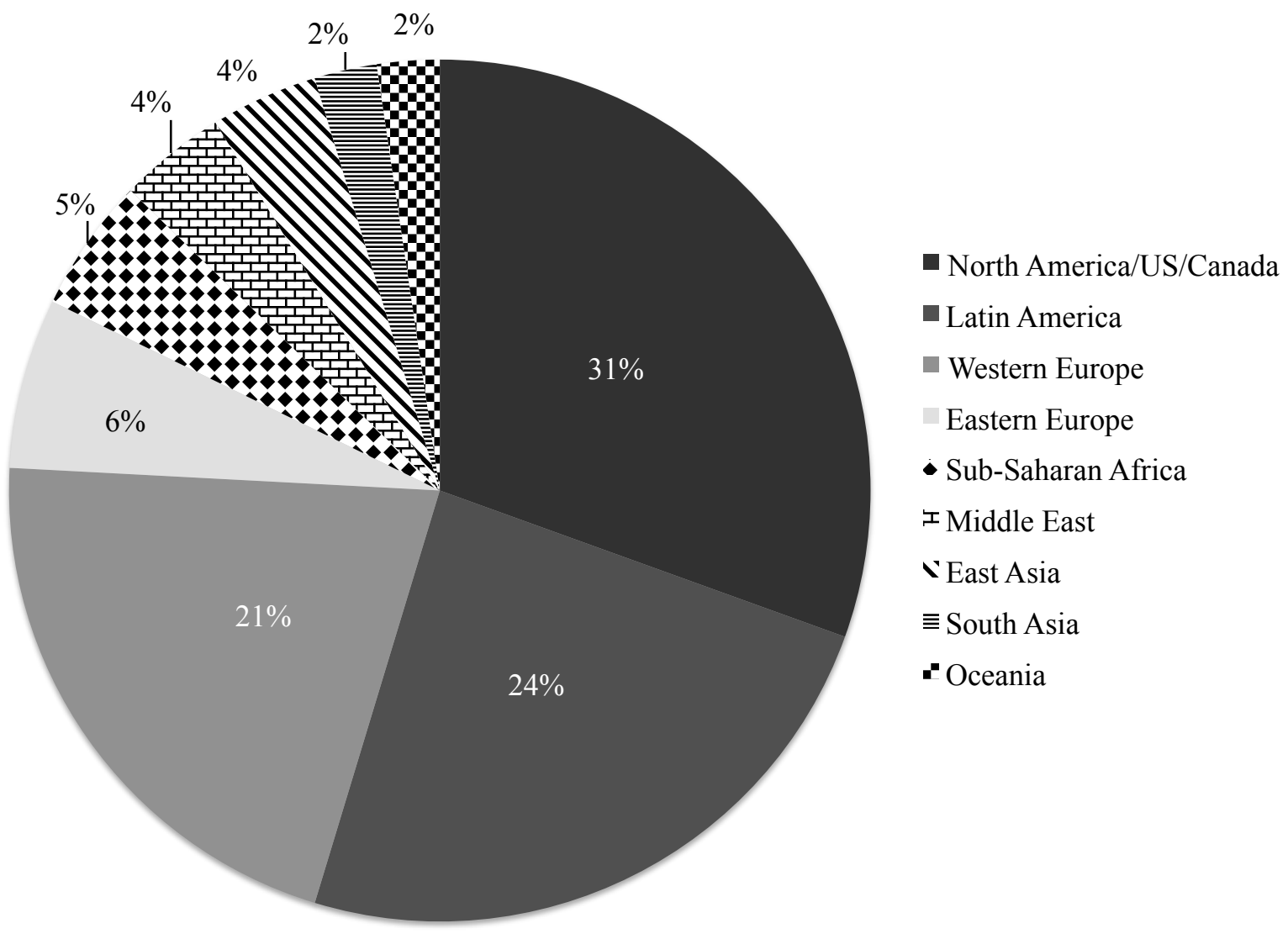

Note: Respondents were asked to rank their regional expertise on a scale from 1 to 5 , with 5 being the highest. The entries in the chart represent the percentage of respondents that ranked their knowledge of a particular region as 5. 


\section{Figure 3}

\section{Expert Weighting of Legislative Powers}
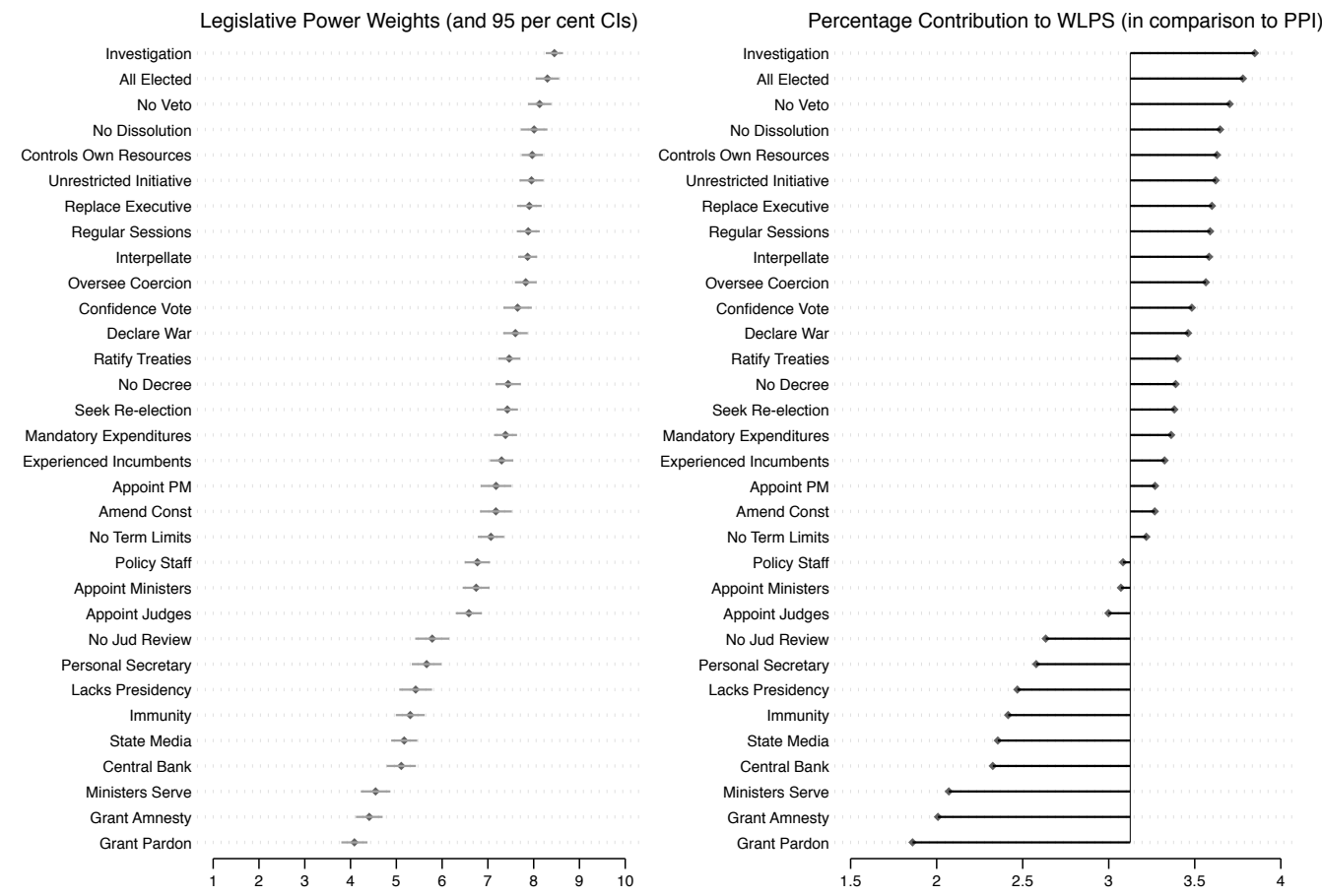
Figure 4

Self-Reported Confidence and Variation in Standard Error
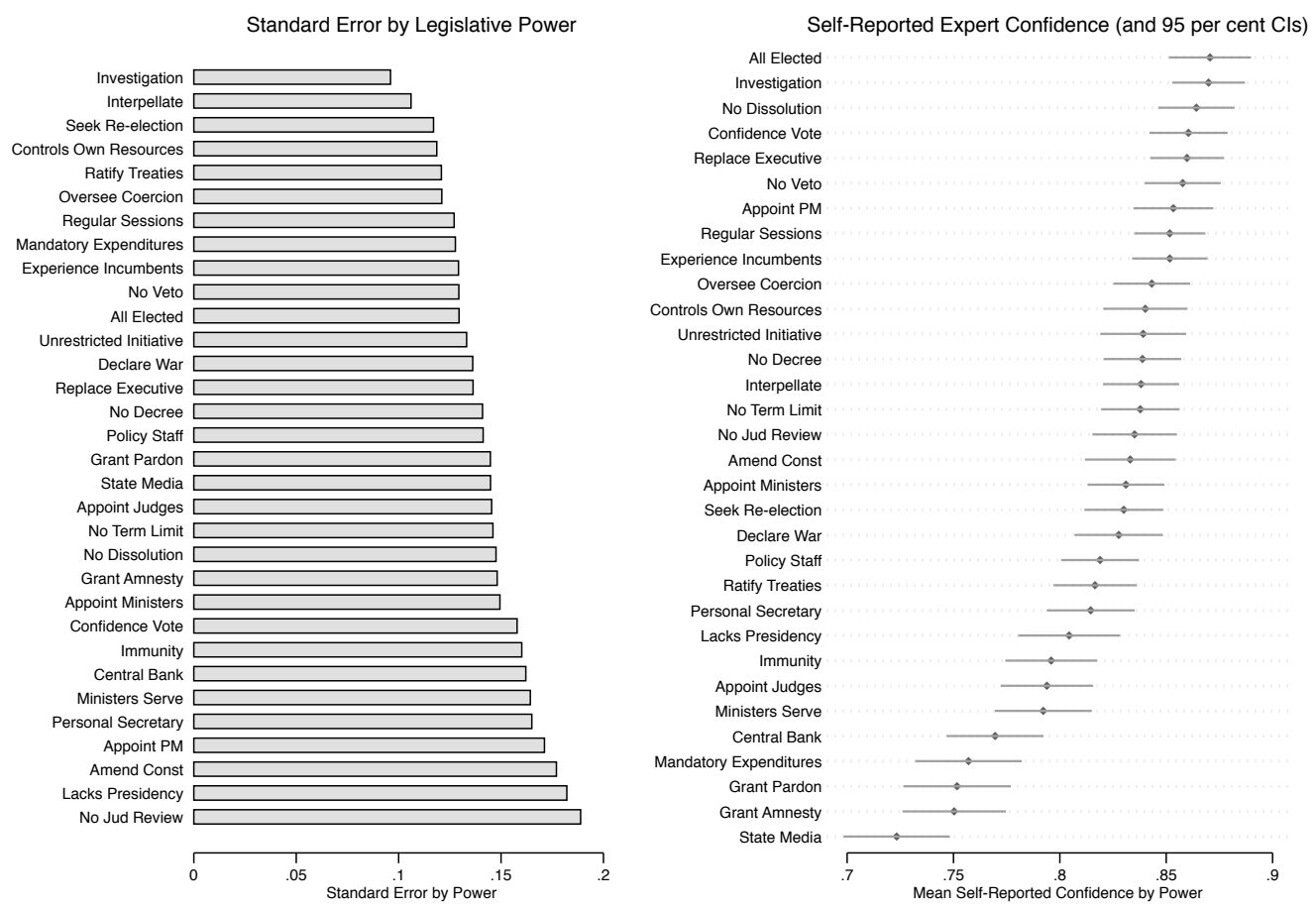


\section{Figure 5}

The Relationship between Importance of Powers and Self-Reported Confidence in Responses

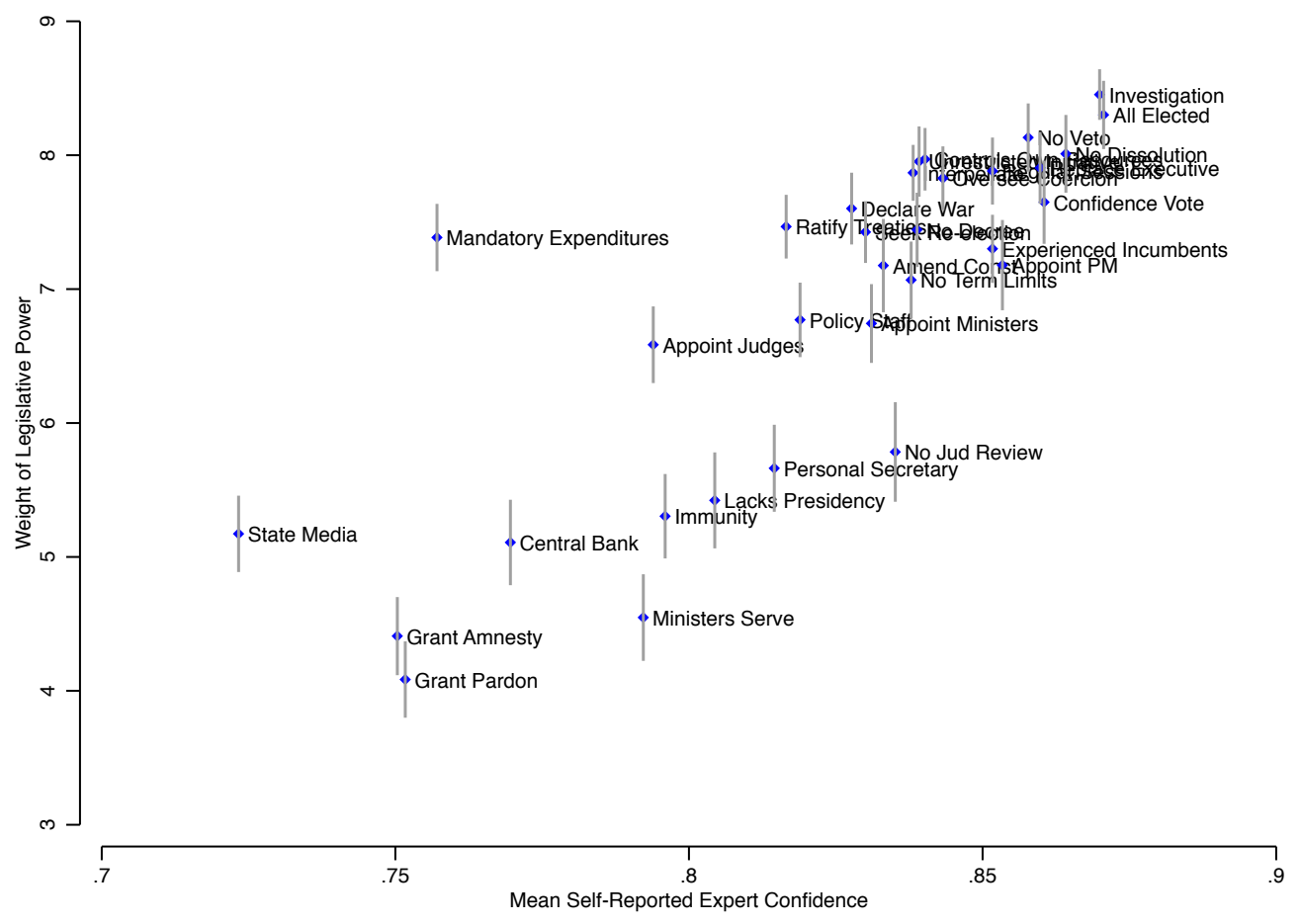


Figure 6

Uncertainty and Disagreement by Expertise and Regime Specialization
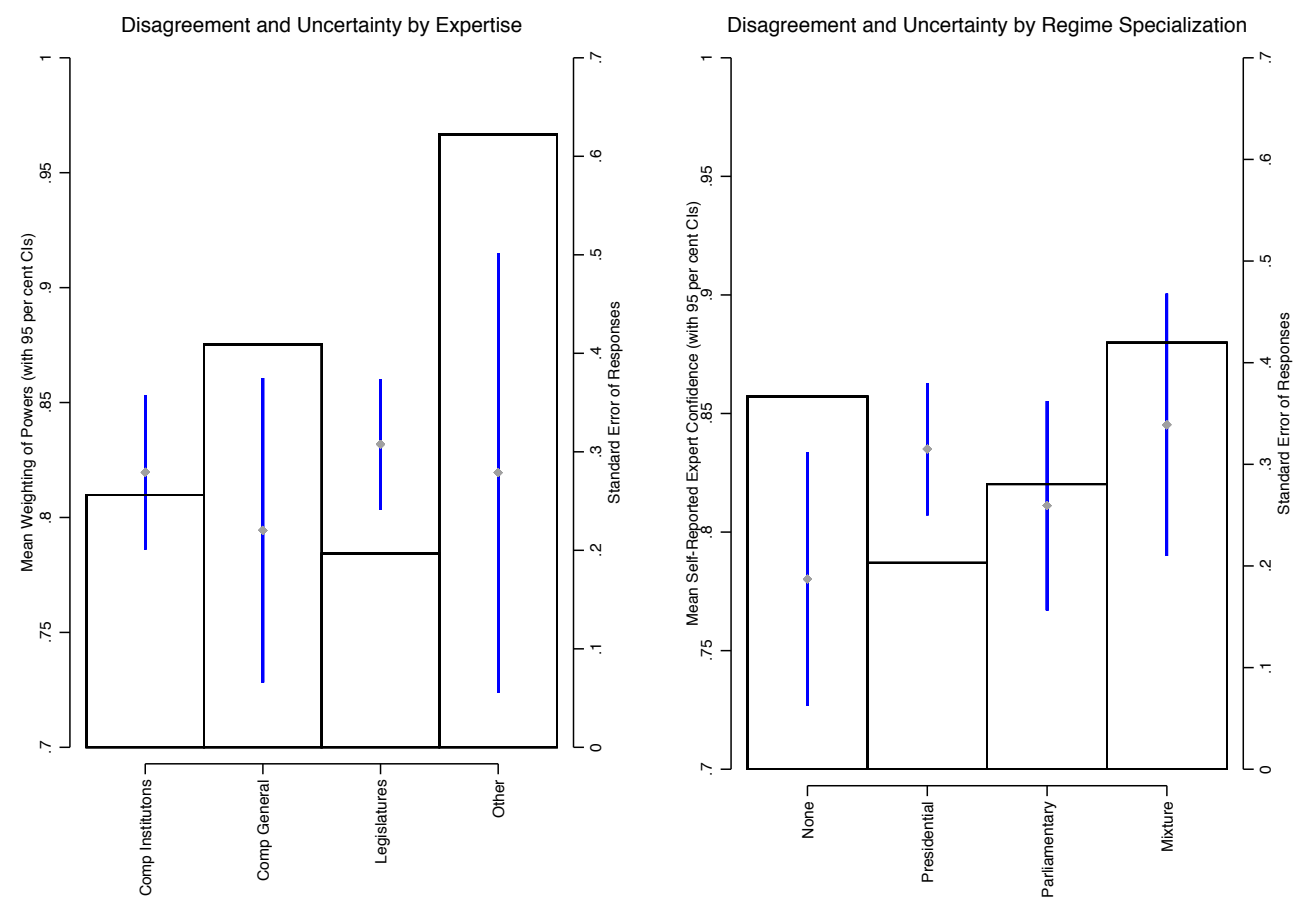
Figure 7

Scatterplot of Country Observations:

PPI versus WLPS

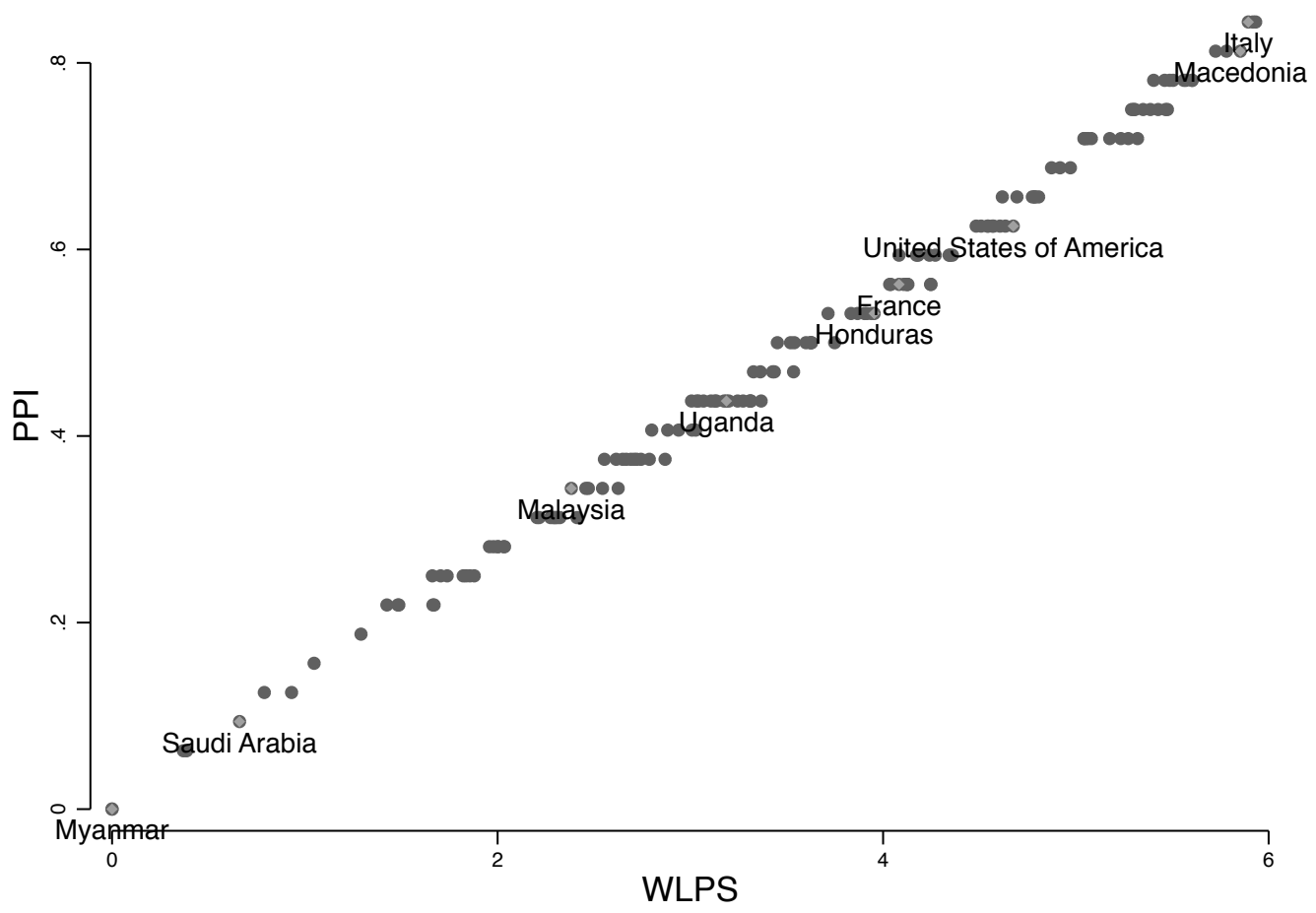

Notes: Data points represent the 158 country observations included in Fish and Kroenig (2009). $r=0.997$ 
Appendix A

Guide to the 32 Legislative Powers

(alphabetical by the shorthand names used in tables and figures)

\begin{tabular}{|c|c|}
\hline $\begin{array}{c}\text { OUR } \\
\text { SHORTHAND }\end{array}$ & $\begin{array}{l}\text { FISH AND KROENIG DESCRIPTION } \\
\text { (SURVEY WORDING) }\end{array}$ \\
\hline All Elected & $\begin{array}{l}\text { All members of the legislature are elected; the executive lacks the } \\
\text { power to appoint any members of the legislature. }\end{array}$ \\
\hline Amend Const & $\begin{array}{l}\text { The legislature alone, without the involvement of any other agencies, } \\
\text { can change the Constitution. }\end{array}$ \\
\hline Appoint Judges & $\begin{array}{l}\text { The legislature reviews and has the right to reject appointments to the } \\
\text { judiciary; or the legislature itself appoints members of the judiciary. }\end{array}$ \\
\hline $\begin{array}{l}\text { Appoint } \\
\text { Ministers }\end{array}$ & $\begin{array}{l}\text { The legislature's approval is required to confirm the appointment of } \\
\text { ministers; or the legislature itself appoints ministers. }\end{array}$ \\
\hline Appoint PM & The legislature appoints the prime minister. \\
\hline Central Bank & The chairman of the central bank is appointed by the legislature. \\
\hline Confidence Vote & The legislature can vote no confidence in the government. \\
\hline $\begin{array}{l}\text { Controls Own } \\
\text { Resources }\end{array}$ & $\begin{array}{l}\text { The legislature controls the resources that finance its own internal } \\
\text { operation and provide for the perquisites of its own members. }\end{array}$ \\
\hline Declare War & The legislature's approval is necessary for the declaration of war. \\
\hline $\begin{array}{l}\text { Experienced } \\
\text { Incumbents }\end{array}$ & $\begin{array}{l}\text { The re-election of incumbent legislators is common enough that at } \\
\text { any given time the legislature contains a significant number of highly } \\
\text { experienced members. }\end{array}$ \\
\hline Grant Amnesty & The legislature has the power to grant amnesty. \\
\hline Grant Pardon & The legislature has the power of pardon. \\
\hline Immunity & $\begin{array}{l}\text { Members of the legislature are immune from arrest and/or criminal } \\
\text { prosecution. }\end{array}$ \\
\hline Interpellate & $\begin{array}{l}\text { The legislature has powers of summons over executive branch } \\
\text { officials and hearings with executive branch officials testifying before } \\
\text { the legislature or its committees are regularly held. }\end{array}$ \\
\hline Investigation & $\begin{array}{l}\text { The legislature can conduct independent investigation of the chief } \\
\text { executive and the agencies of the executive. }\end{array}$ \\
\hline Lacks Presidency & $\begin{array}{l}\text { The country lacks a presidency entirely or there is a presidency, but } \\
\text { the president is elected by the legislature. }\end{array}$ \\
\hline $\begin{array}{l}\text { Mandatory } \\
\text { Expenditures }\end{array}$ & $\begin{array}{l}\text { Expenditure of funds appropriated by the legislature is mandatory; } \\
\text { the executive lacks the power to impound funds appropriated by the }\end{array}$ \\
\hline
\end{tabular}




\begin{tabular}{|c|c|}
\hline & legislature. \\
\hline Ministers Serve & Ministers may serve simultaneously as members of the legislature. \\
\hline No Decree & $\begin{array}{l}\text { Any executive initiative on legislation requires ratification or } \\
\text { approval by the legislature before it takes effect; that is, the executive } \\
\text { lacks decree power. }\end{array}$ \\
\hline No Dissolution & The legislature is immune from dissolution by the executive. \\
\hline No Jud Review & The legislature's laws are supreme and not subject to judicial review. \\
\hline No Term Limits & Legislators are eligible for re-election without any restriction \\
\hline No Veto & $\begin{array}{l}\text { Laws passed by the legislature are veto-proof or essentially veto- } \\
\text { proof; that is, the executive lacks veto power, or has veto power but } \\
\text { the veto can be overridden by a majority in the legislature. }\end{array}$ \\
\hline $\begin{array}{l}\text { Oversee } \\
\text { Coercion }\end{array}$ & $\begin{array}{l}\text { The legislature has effective powers of oversight over the agencies of } \\
\text { coercion (the military, organs of law enforcement, intelligence } \\
\text { services, and the secret police). }\end{array}$ \\
\hline $\begin{array}{l}\text { Personal } \\
\text { Secretary }\end{array}$ & Each legislator has a personal secretary. \\
\hline Policy Staff & $\begin{array}{l}\text { Each legislator has at least one non-secretarial staff member with } \\
\text { policy expertise. }\end{array}$ \\
\hline Ratify Treaties & $\begin{array}{l}\text { The legislature's approval is necessary to ratify treaties with foreign } \\
\text { countries. }\end{array}$ \\
\hline Regular Sessions & The legislature is regularly in session. \\
\hline $\begin{array}{l}\text { Replace } \\
\text { Executive }\end{array}$ & $\begin{array}{l}\text { The legislature alone, without the involvement of any other agencies, } \\
\text { can impeach the president or replace the prime minister. }\end{array}$ \\
\hline Seek Re-Election & $\begin{array}{l}\text { A seat in the legislature is an attractive enough position that } \\
\text { legislators are generally interested in and seek re-election. }\end{array}$ \\
\hline State Media & $\begin{array}{l}\text { The legislature has a substantial voice in the operation of the state- } \\
\text { owned media. }\end{array}$ \\
\hline $\begin{array}{l}\text { Unrestricted } \\
\text { Initiative }\end{array}$ & $\begin{array}{l}\text { The legislature has the right to initiate bills in all policy jurisdictions; } \\
\text { the executive lacks gatekeeping authority. }\end{array}$ \\
\hline
\end{tabular}

Source: Fish and Kroenig 2009. 
Appendix B

Country Scores and Ranks for PPI and WLPS, 158 Parliaments, circa 2005-2007

\begin{tabular}{|c|c|c|c|c|c|}
\hline COUNTRY & PPI & RANK & WLPS & SE & RANK \\
\hline Afghanistan & 0.3750 & 16 & 2.691512 & 0.051 & 111 \\
\hline Albania & 0.7500 & 4 & 5.348923 & 0.105 & 18 \\
\hline Algeria & 0.2500 & 20 & 1.879012 & 0.033 & 136 \\
\hline Angola & 0.4375 & 14 & 3.006335 & 0.061 & 102 \\
\hline Argentina & 0.5000 & 12 & 3.600190 & 0.067 & 76 \\
\hline Armenia & 0.5625 & 10 & 4.034417 & 0.075 & 64 \\
\hline Australia & 0.6250 & 8 & 4.566934 & 0.086 & 44 \\
\hline Austria & 0.7188 & 5 & 5.080553 & 0.098 & 26 \\
\hline Azerbaijan & 0.4375 & 14 & 3.135557 & 0.060 & 94 \\
\hline Bahrain & 0.1875 & 22 & 1.291491 & 0.026 & 148 \\
\hline Bangladesh & 0.5938 & 9 & 4.342378 & 0.083 & 51 \\
\hline Belarus & 0.2500 & 20 & 1.661423 & 0.036 & 144 \\
\hline Belgium & 0.7500 & 4 & 5.386719 & 0.104 & 17 \\
\hline Benin & 0.5625 & 10 & 4.129012 & 0.075 & 58 \\
\hline Bhutan & 0.2188 & 21 & 1.487859 & 0.032 & 145 \\
\hline Bolivia & 0.4375 & 14 & 3.127111 & 0.057 & 95 \\
\hline Bosnia-Herzegovina & 0.6250 & 8 & 4.544341 & 0.084 & 45 \\
\hline Botswana & 0.4375 & 14 & 3.068623 & 0.062 & 97 \\
\hline Brazil & 0.5625 & 10 & 4.124472 & 0.076 & 59 \\
\hline Bulgaria & 0.7813 & 3 & 5.603251 & 0.107 & 7 \\
\hline Burkina Faso & 0.5313 & 11 & 3.915752 & 0.071 & 67 \\
\hline Burundi & 0.4063 & 15 & 2.799726 & 0.058 & 106 \\
\hline Cambodia & 0.5938 & 9 & 4.182221 & 0.086 & 56 \\
\hline Cameroon & 0.2500 & 20 & 1.821791 & 0.034 & 139 \\
\hline Canada & 0.7188 & 5 & 5.043813 & 0.099 & 29 \\
\hline Central Afr. Rep. & 0.3438 & 17 & 2.470967 & 0.047 & 118 \\
\hline Chad & 0.2188 & 21 & 1.670714 & 0.029 & 142 \\
\hline Chile & 0.5625 & 10 & 4.040329 & 0.075 & 63 \\
\hline China & 0.3438 & 17 & 2.625633 & 0.044 & 114 \\
\hline Colombia & 0.5625 & 10 & 4.124472 & 0.076 & 59 \\
\hline Comoros & 0.3750 & 16 & 2.648965 & 0.052 & 113 \\
\hline Congo (Brazzaville) & 0.3750 & 16 & 2.721812 & 0.050 & 109 \\
\hline Congo (Kinshasa) & 0.2500 & 20 & 1.856313 & 0.033 & 137 \\
\hline Costa Rica & 0.5313 & 11 & 3.833720 & 0.072 & 70 \\
\hline Cote d'Ivoire & 0.3750 & 16 & 2.708615 & 0.050 & 110 \\
\hline Croatia & 0.7813 & 3 & 5.603251 & 0.107 & 7 \\
\hline Cuba & 0.2813 & 19 & 2.002745 & 0.039 & 132 \\
\hline Cyprus & 0.4063 & 15 & 3.008868 & 0.055 & 101 \\
\hline Czech Republic & 0.8125 & 2 & 5.781567 & 0.113 & 5 \\
\hline
\end{tabular}




\begin{tabular}{|c|c|c|c|c|c|}
\hline Denmark & 0.7813 & 3 & 5.570946 & 0.108 & 8 \\
\hline Dominican Republic & 0.4063 & 15 & 2.939611 & 0.056 & 103 \\
\hline Ecuador & 0.5313 & 11 & 3.714633 & 0.072 & 72 \\
\hline Egypt & 0.2813 & 19 & 2.031144 & 0.037 & 131 \\
\hline El Salvador & 0.5938 & 9 & 4.240815 & 0.080 & 55 \\
\hline Eritrea & 0.2500 & 20 & 1.738492 & 0.036 & 140 \\
\hline Estonia & 0.7500 & 4 & 5.475296 & 0.103 & 12 \\
\hline Ethiopia & 0.5000 & 12 & 3.520165 & 0.071 & 79 \\
\hline Fiji & 0.6250 & 8 & 4.606313 & 0.084 & 42 \\
\hline Finland & 0.7188 & 5 & 5.041913 & 0.101 & 30 \\
\hline France & 0.5625 & 10 & 4.082982 & 0.075 & 61 \\
\hline Gabon & 0.4375 & 14 & 3.273860 & 0.060 & 89 \\
\hline Gambia & 0.3125 & 18 & 2.412056 & 0.039 & 120 \\
\hline Georgia & 0.5938 & 9 & 4.347762 & 0.079 & 50 \\
\hline Germany & 0.8438 & 1 & 5.932961 & 0.118 & 1 \\
\hline Ghana & 0.4688 & 13 & 3.436022 & 0.063 & 81 \\
\hline Greece & 0.8125 & 2 & 5.725190 & 0.114 & 6 \\
\hline Guatemala & 0.5000 & 12 & 3.621938 & 0.065 & 75 \\
\hline Guinea & 0.3125 & 18 & 2.310811 & 0.040 & 123 \\
\hline Guinea-Bissau & 0.2500 & 20 & 1.836676 & 0.036 & 138 \\
\hline Guyana & 0.3750 & 16 & 2.667758 & 0.053 & 112 \\
\hline Haiti & 0.4375 & 14 & 3.314928 & 0.059 & 86 \\
\hline Honduras & 0.5313 & 11 & 3.953758 & 0.070 & 65 \\
\hline Hungary & 0.7500 & 4 & 5.306905 & 0.104 & 20 \\
\hline India & 0.6250 & 8 & 4.508657 & 0.087 & 47 \\
\hline Indonesia & 0.5625 & 10 & 4.246410 & 0.075 & 54 \\
\hline Iran & 0.4375 & 14 & 3.307327 & 0.058 & 88 \\
\hline Iraq & 0.6250 & 8 & 4.634924 & 0.086 & 40 \\
\hline Ireland & 0.6563 & 7 & 4.774493 & 0.089 & 37 \\
\hline Israel & 0.7500 & 4 & 5.426942 & 0.104 & 15 \\
\hline Italy & 0.8438 & 1 & 5.894848 & 0.117 & 3 \\
\hline Jamaica & 0.6250 & 8 & 4.542546 & 0.087 & 46 \\
\hline Japan & 0.6563 & 7 & 4.807010 & 0.090 & 34 \\
\hline Jordan & 0.2188 & 21 & 1.482686 & 0.031 & 146 \\
\hline Kazakhstan & 0.3750 & 16 & 2.615287 & 0.052 & 115 \\
\hline Kenya & 0.3125 & 18 & 2.204603 & 0.044 & 129 \\
\hline Kuwait & 0.3750 & 16 & 2.554265 & 0.052 & 116 \\
\hline Kyrgyzstan & 0.4688 & 13 & 3.327808 & 0.065 & 85 \\
\hline Laos & 0.2813 & 19 & 2.001267 & 0.039 & 133 \\
\hline Latvia & 0.7813 & 3 & 5.403822 & 0.110 & 16 \\
\hline Lebanon & 0.5000 & 12 & 3.451541 & 0.072 & 80 \\
\hline Lesotho & 0.5313 & 11 & 3.939295 & 0.073 & 66 \\
\hline Liberia & 0.4375 & 14 & 3.312500 & 0.060 & 87 \\
\hline
\end{tabular}




\begin{tabular}{|c|c|c|c|c|c|}
\hline Libya & 0.1250 & 24 & 0.790013 & 0.019 & 151 \\
\hline Lithuania & 0.7813 & 3 & 5.487226 & 0.108 & 11 \\
\hline Macedonia & 0.8125 & 2 & 5.853569 & 0.112 & 4 \\
\hline Madagascar & 0.4063 & 15 & 2.882707 & 0.055 & 104 \\
\hline Malawi & 0.3750 & 16 & 2.787162 & 0.050 & 107 \\
\hline Malaysia & 0.3438 & 17 & 2.382601 & 0.052 & 121 \\
\hline Mali & 0.3438 & 17 & 2.544447 & 0.046 & 117 \\
\hline Mauritania & 0.3125 & 18 & 2.323163 & 0.043 & 122 \\
\hline Mauritius & 0.6563 & 7 & 4.786634 & 0.090 & 36 \\
\hline Mexico & 0.4375 & 14 & 3.199852 & 0.058 & 91 \\
\hline Moldova & 0.7500 & 4 & 5.299937 & 0.103 & 21 \\
\hline Mongolia & 0.8438 & 1 & 5.918497 & 0.118 & 2 \\
\hline Morocco & 0.3125 & 18 & 2.295925 & 0.042 & 125 \\
\hline Mozambique & 0.4375 & 14 & 3.032517 & 0.060 & 99 \\
\hline Myanmar & 0.0000 & 27 & 0.000000 & 0.000 & 155 \\
\hline Namibia & 0.5000 & 12 & 3.749050 & 0.065 & 71 \\
\hline Nepal & 0.4375 & 14 & 3.106947 & 0.063 & 96 \\
\hline Netherlands & 0.7813 & 3 & 5.560283 & 0.109 & 9 \\
\hline New Zealand & 0.6875 & 6 & 4.971917 & 0.097 & 31 \\
\hline Nicaragua & 0.6875 & 6 & 4.918180 & 0.093 & 32 \\
\hline Niger & 0.5000 & 12 & 3.628906 & 0.067 & 73 \\
\hline Nigeria & 0.4688 & 13 & 3.535790 & 0.061 & 78 \\
\hline North Korea & 0.1250 & 24 & 0.931377 & 0.017 & 150 \\
\hline Norway & 0.7188 & 5 & 5.320312 & 0.099 & 19 \\
\hline Oman & 0.1563 & 23 & 1.048247 & 0.023 & 149 \\
\hline Pakistan & 0.4375 & 14 & 3.245566 & 0.061 & 90 \\
\hline Panama & 0.5000 & 12 & 3.539379 & 0.069 & 77 \\
\hline Papua New Guinea & 0.6563 & 7 & 4.787584 & 0.091 & 35 \\
\hline Paraguay & 0.5625 & 10 & 4.107369 & 0.075 & 60 \\
\hline Peru & 0.6563 & 7 & 4.694573 & 0.090 & 38 \\
\hline Philippines & 0.5625 & 10 & 4.248944 & 0.073 & 53 \\
\hline Poland & 0.7500 & 4 & 5.289168 & 0.104 & 22 \\
\hline Portugal & 0.6250 & 8 & 4.482897 & 0.084 & 48 \\
\hline Qatar & 0.2188 & 21 & 1.425887 & 0.032 & 147 \\
\hline Romania & 0.7188 & 5 & 5.063344 & 0.098 & 27 \\
\hline Russia & 0.4375 & 14 & 3.042969 & 0.061 & 98 \\
\hline Rwanda & 0.4688 & 13 & 3.363387 & 0.065 & 84 \\
\hline Saudi Arabia & 0.0938 & 25 & 0.661634 & 0.013 & 152 \\
\hline Senegal & 0.4375 & 14 & 3.367610 & 0.056 & 83 \\
\hline Serbia \& Montenegro & 0.6875 & 6 & 4.874050 & 0.095 & 33 \\
\hline Sierra Leone & 0.4063 & 15 & 3.027872 & 0.057 & 100 \\
\hline Singapore & 0.3750 & 16 & 2.743982 & 0.052 & 108 \\
\hline Slovakia & 0.7188 & 5 & 5.272065 & 0.098 & 23 \\
\hline
\end{tabular}




\begin{tabular}{|c|c|c|c|c|c|}
\hline Slovenia & 0.7500 & 4 & 5.465477 & 0.103 & 13 \\
\hline Somalia & 0.0000 & 27 & 0.000000 & 0.000 & 155 \\
\hline South Africa & 0.6250 & 8 & 4.573268 & 0.085 & 43 \\
\hline South Korea & 0.5938 & 9 & 4.359903 & 0.079 & 49 \\
\hline Spain & 0.7188 & 5 & 5.175887 & 0.100 & 25 \\
\hline Sri Lanka & 0.5000 & 12 & 3.627111 & 0.069 & 74 \\
\hline Sudan & 0.2188 & 21 & 1.664485 & 0.028 & 143 \\
\hline Swaziland & 0.2500 & 20 & 1.704814 & 0.035 & 141 \\
\hline Sweden & 0.7188 & 5 & 5.233425 & 0.100 & 24 \\
\hline Switzerland & 0.7188 & 5 & 5.053526 & 0.100 & 28 \\
\hline Syria & 0.3125 & 18 & 2.287268 & 0.043 & 126 \\
\hline Taiwan & 0.5938 & 9 & 4.271009 & 0.078 & 52 \\
\hline Tajikistan & 0.3125 & 18 & 2.215583 & 0.044 & 128 \\
\hline Tanzania & 0.3125 & 18 & 2.300887 & 0.040 & 124 \\
\hline Thailand & 0.5938 & 9 & 4.173459 & 0.084 & 57 \\
\hline Timor-Leste & 0.4688 & 13 & 3.427154 & 0.065 & 82 \\
\hline Togo & 0.3750 & 16 & 2.869405 & 0.050 & 105 \\
\hline Trinidad \& Tobago & 0.5313 & 11 & 3.867821 & 0.075 & 69 \\
\hline Tunisia & 0.2813 & 19 & 1.958193 & 0.041 & 135 \\
\hline Turkey & 0.7813 & 3 & 5.461043 & 0.108 & 14 \\
\hline Turkmenistan & 0.0625 & 26 & 0.370249 & 0.009 & 154 \\
\hline Uganda & 0.4375 & 14 & 3.187289 & 0.058 & 92 \\
\hline Ukraine & 0.5938 & 9 & 4.082664 & 0.083 & 62 \\
\hline United Arab Emirates & 0.0625 & 26 & 0.386613 & 0.010 & 153 \\
\hline United Kingdom & 0.7813 & 3 & 5.504645 & 0.110 & 10 \\
\hline United States & 0.6250 & 8 & 4.675570 & 0.082 & 39 \\
\hline Uruguay & 0.6563 & 7 & 4.618771 & 0.089 & 41 \\
\hline Uzbekistan & 0.2813 & 19 & 2.036318 & 0.038 & 130 \\
\hline Venezuela & 0.5313 & 11 & 3.904033 & 0.068 & 68 \\
\hline Vietnam & 0.3438 & 17 & 2.457876 & 0.047 & 119 \\
\hline Yemen & 0.4375 & 14 & 3.175253 & 0.059 & 93 \\
\hline Zambia & 0.2813 & 19 & 1.979307 & 0.039 & 134 \\
\hline Zimbabwe & 0.3125 & 18 & 2.274704 & 0.043 & 127 \\
\hline
\end{tabular}

Notes: produces only 27 discriminating ranks, so many countries share the same rank (e.g. Germany, Italy and Mongolia, with identical PPI scores of 0.8438 , share $1^{\text {st }}$ place in the ranking). WLPS produces 155 discriminating ranks. There are "ties" between Croatia and Bulgaria for $7^{\text {th }}$ place and between Brazil and Colombia for $59^{\text {th }}$ place. Myanmar and Somalia are tied for last place in both rankings: since neither country possess any of the 32 powers identified by Fish and Kroenig (2009), they score zero on both measures of legislative power. 


\section{Appendix C \\ Mean Importance Assigned to Each of the 32 Legislative Powers}

\begin{tabular}{|c|c|c|c|c|c|}
\hline Power & Score & SE & \multicolumn{2}{|c|}{ [95 per cent CIs] } & Confidence \\
\hline All Elected & 8.300675 & 0.1294939 & 8.045827 & 8.555525 & 0.87 \\
\hline Amend Const & 7.175676 & 0.1770394 & 6.827255 & 7.524096 & 0.83 \\
\hline Appoint Judges & 6.584459 & 0.1453938 & 6.298319 & 6.870600 & 0.79 \\
\hline Appoint Ministers & 6.743243 & 0.1494564 & 6.449107 & 7.037379 & 0.83 \\
\hline Appoint PM & 7.179054 & 0.1712070 & 6.842112 & 7.515996 & 0.85 \\
\hline Central Bank & 5.108108 & 0.1621030 & 4.789083 & 5.427133 & 0.77 \\
\hline $\begin{array}{l}\text { Confidence Vote } \\
\text { Controls Own }\end{array}$ & 7.648649 & 0.1578406 & 7.338012 & 7.959285 & 0.86 \\
\hline Resources & 7.969594 & 0.1186235 & 7.736139 & 8.203051 & 0.84 \\
\hline $\begin{array}{l}\text { Declare War } \\
\text { Experienced }\end{array}$ & 7.601351 & 0.1361636 & 7.333376 & 7.869327 & 0.83 \\
\hline Incumbents & 7.300676 & 0.1292283 & 7.046350 & 7.555002 & 0.85 \\
\hline Grant Amnesty & 4.408784 & 0.1481114 & 4.117295 & 4.700273 & 0.75 \\
\hline Grant Pardon & 4.084459 & 0.1448018 & 3.799484 & 4.369435 & 0.75 \\
\hline Immunity & 5.304054 & 0.1601160 & 4.988940 & 5.619168 & 0.80 \\
\hline Interpellate & 7.868243 & 0.1060396 & 7.659553 & 8.076933 & 0.84 \\
\hline Investigation & 8.452703 & 0.0960356 & 8.263701 & 8.641705 & 0.87 \\
\hline $\begin{array}{l}\text { Lacks Presidency } \\
\text { Mandatory }\end{array}$ & 5.422297 & 0.1821203 & 5.063878 & 5.780717 & 0.80 \\
\hline Expenditures & 7.385135 & 0.1277064 & 7.133804 & 7.636466 & 0.76 \\
\hline Ministers Serve & 4.547297 & 0.1643062 & 4.223937 & 4.870658 & 0.79 \\
\hline No Decree & 7.442567 & 0.1409600 & 7.165153 & 7.719982 & 0.84 \\
\hline No Dissolution & 8.010135 & 0.1475471 & 7.719757 & 8.300513 & 0.86 \\
\hline No Judicial Review & 5.783784 & 0.1888486 & 5.412123 & 6.155445 & 0.84 \\
\hline No Term Limits & 7.067567 & 0.1460524 & 6.780131 & 7.355004 & 0.84 \\
\hline No Veto & 8.131757 & 0.1293887 & 7.877115 & 8.386398 & 0.86 \\
\hline Oversee Coercion & 7.827703 & 0.1210833 & 7.589406 & 8.065999 & 0.84 \\
\hline Personal Sec & 5.662162 & 0.1650322 & 5.337372 & 5.986952 & 0.81 \\
\hline Policy Staff & 6.770270 & 0.1412584 & 6.492268 & 7.048272 & 0.82 \\
\hline Ratify Treaties & 7.466216 & 0.1208679 & 7.228343 & 7.704089 & 0.82 \\
\hline Regular Sessions & 7.881757 & 0.1271116 & 7.631596 & 8.131917 & 0.85 \\
\hline Replace Executive & 7.905406 & 0.1363482 & 7.637067 & 8.173744 & 0.86 \\
\hline Seek Re-election & 7.425676 & 0.1170510 & 7.195315 & 7.656036 & 0.83 \\
\hline State Media & 5.172297 & 0.1448542 & 4.887218 & 5.457376 & 0.72 \\
\hline Unrestricted Initiative & 7.952703 & 0.1332037 & 7.690553 & 8.214852 & 0.84 \\
\hline
\end{tabular}




\section{Endnotes}

${ }^{1}$ The authors are grateful to M. Stephen Fish and Matthew Kroenig for innovating the Parliamentary Powers Index, and also to Mariana Llanos, Gisela Sin, and Nina Wiesehomeier for assistance in developing our survey and expert database. The School of Politics and International Relations at ANU provided financial support for building the email list. We are also grateful to Despina Alexiadou, Guillermo Rosas, Christopher Kam, and three anonymous LSQ reviewers for helpful comments on earlier versions of the manuscript. A special vote of thanks is reserved for the 296 colleagues who sacrificed valuable time in order to complete our online survey.

${ }^{2}$ The literature is vast and here we offer some representative citations only. On measurement of presidential power, see Shugart and Carey (1992), Metcalf (2000), Fortin (2013), and Doyle and Elgie (2015); on party system institutionalization, see Mainwaring and Scully (1995) and Jones (2010); on electoral system design, see Teorell and Lindstedt (2014); on comparative constitutions, see Cheibub, Elkins, and Ginsburg (2014); on cabinets, see Martin and Vanberg (2011) and Martínez-Gallardo and Schleiter (2014); on judicial independence, see Ríos-Figueroa and Staton (2012).

${ }^{3}$ Fish and Kroenig distinguish between the Legislative Powers Survey, which is the country-level count of the 32 relevant legislative attributes, and a Parliamentary Powers Index, which is the average of the binary variables in the LPS. Since the two indicators carry the same information, we will refer here to the PPI for simplicity.

${ }^{4}$ For a sampling of recent studies using the PPI as an independent variable, see Clark (2014), Ecevit and Karakoç (2015), O’Dwyer (2014), and Schwindt-Bayer and Squire (2014).

${ }^{5}$ For a critique of checklist measures of presidential power, see Metcalf (2000).

${ }^{6}$ The order of the questions was randomized prior to the start of the survey. All respondents received the questions in the same order.

${ }^{7}$ We pre-tested the survey by using the online platform to complete the questionnaire ourselves. We also asked a number of our graduate students to take the survey and give us feedback on the interface. The pretest responses were then discarded from the dataset.

${ }^{8}$ The text of the self-reported expertise question was as follows: "Which of the following statements best describes you as a professional? (1) I consider myself to be a specialist in legislative studies, (2) I consider myself to be a specialist in comparative political institutions more generally, (3) I consider myself to be a generalist in comparative political analysis, but not predominantly in institutions, (4) Other (please specify)."

${ }^{9}$ The text of the question was as follows: "As a professional in political research, can you please rate your level of specialised knowledge of the following world regions on a scale from 1 to 5 , with 1 representing very low specialised knowledge and 5 representing very high: Western Europe, North America 
(US/Canada), Eastern Europe/post-Soviet, Latin America, Sub-Saharan Africa, Middle East/North Africa, East Asia, South Asia, Oceania.”

${ }^{10}$ In reality, survey respondents often interpret scales differently, a problem known as differential item functioning (DIF) (see Brady 1985; King et al. 2004). Typically, for a large public opinion survey, we could address this problem using Aldrich and McKelvey's (1977) seminal method for correcting the perceptual biases of respondents in surveys (see also Hare et al. 2014). It is not feasible for us to perform a similar rescaling exercise here, because our data do not provide us with a perceptual fixed point with which to anchor the A-M transformation. Given that our stimuli are legislative powers (which political scientists do not experience personally), we do not have a self-placement measure on the same scale as the stimuli.

${ }^{11}$ To help users assess the utility of our data, we also report standard errors for each country. These are not calculated by country, but rather reflect the mean standard error (as calculated from our survey) for each of the legislative powers present in each country $i$.

12 The Fish and Kroenig dataset contains 5056 discrete observations (32 powers across 158 national legislatures), all of which are either zeroes or ones. Of the 5056 observations, some 2565 (51\%) are in fact zeroes, signifying the absences of powers in parliaments. This means that we are reweighting only $49 \%$ of the observations and leaving the rest unaltered.

${ }^{13}$ WLPS is slightly better correlated than PPI with standard measures of democracy, such as Freedom House and Polity as of 2005. It is also slightly more correlated with a measure of historical "democratic stock" as inspired by Gerring et al. (2005), which we operationalize as the sum of a country's Polity2 scores between 1950 and 2000 .

${ }^{14}$ All institutional configurations discussed here are accurate as of the time of the Fish and Kroenig survey in the mid-2000s. The Ukrainian examples are based on the constitution of 2004, which has since been amended.

${ }^{15}$ The full list of country scores can be found in Appendix B.

${ }^{16}$ For example, many of the PPI powers can be translated quite easily to analogous variables in the Comparative Constitutions Project (http://comparativeconstitutionsproject.org). 